\title{
Management Of Blood Hemoglobin Level Through The Consumption Of Lemuru Fish Stick As A Snack Food In Young Women Suffering From Anemia
}

\author{
Riris Oppusunggu*, Bernike Doloksaribu \\ Department of Nutrition, Politeknik Kesehatan Medan, Deli Serdang, Sumatera Utara
}

\begin{abstract}
Anemia is a condition where a person's hemoglobin (Hb) level in the blood is lower than normal. Adolescent girls are one group at risk of suffering from anemia, because they are lack in iron intake and having chronic blood loss during menstruation. The aim of this community service was to increase the knowledge of young women, especially those suffering from anemia, about the management of blood hemoglobin levels. In addition, it is essential to increase the knowledge of young women on the procedure to make lemuru fish stick, a snack to increase the blood hemoglobin levels of young women. The Community Service was held in Nusantara Lubuk Pakam with many activities, including examination of hemoglobin levels, counseling about anemia as well as demonstration of making lemuru fish sticks, snacks to overcome anemia. The result of the activity was successfully achieved, so that the young women have good understanding in the procedure for making the fish stick.
\end{abstract}

Keywords: Lemuru fish stick, Knowledge, Hemoglobin level, Anemia

\begin{abstract}
Abstrak. Anemia adalah suatu kondisi di mana kadar hemoglobin (Hb) seseorang dalam darah lebih rendah dari normal. Gadis remaja adalah satu kelompok yang berisiko menderita anemia. Penyebab utama anemia pada wanita muda adalah kurangnya asupan zat besi, kehilangan darah kronis selama menstruasi. Tujuan dari pengabdian masyarakat ini adalah untuk meningkatkan pengetahuan wanita muda, terutama mereka yang menderita anemia, tentang pengelolaan kadar hemoglobin darah dan untuk meningkatkan pengetahuan wanita muda dalam memahami prosedur membuat lemuru ikan sebagai camilan untuk meningkatkan kadar hemoglobin wanita muda di Nusantara Lubuk Pakam. Bentuk kegiatan pengabdian kepada masyarakat tentang anemia, penyuluhan tentang ikan lemuru, pemeriksaan kadar hemoglobin, demonstrasi pembuatan produk ikan lemuru untuk meningkatkan kadar hemoglobin darah untuk mengatasi anemia. Hasil dari kegiatan ini adalah
\end{abstract}

\footnotetext{
*Corresponding author at: Politeknik Kesehatan Medan, Jalan Negara Simpang Tanjung Garbus Lubuk Pakam

E-mail address: ririsoppusunggu@gmail.com
} 
peningkatan pengetahuan wanita muda dalam memahami prosedur untuk membuat ikan stick sebagai makanan ringan untuk meningkatkan kadar hemoglobin.

Kata Kunci: Stick ikan lemuru, Pengetahuan, Tingkat hemoglobin, Anemia Received 25 September 2019 | Revised 20 October 2019 | Accepted 25 November 2019

\section{Introduction}

Anemia is a condition where the level of Hemoglobin $(\mathrm{Hb})$ of a person in the blood is lower than normal. Young women are one of the risk groups of anemia [1], due to less iron intake, chronic blood loss during childbirth, and blood loss in menstrual period [2].

Less iron intake can be influenced by several factors, namely, lack of animal food consumption as the source of easily absorbed (heme iron) iron. In contrast, although vegetable contain high iron, the iron is a non-heme iron which is difficult to absorb. Therefore, there is essential to take a large portion of vegetables to meet iron need in the day. It can also be due to lack of nutrients that play a role in the absorption of iron such as, protein and vitamin C. Moreover, the consumption of foods high in fiber, tannins and acid can inhibit the absorption of iron. Various factors can also affect the occurrence of iron-nutrient anemia, such as menstrual patterns and nutritional status. In addition, Vitamin B12 and folate deficiency Anemia also often occurs in adolescents due to the lack of consumption of such nutrient substances [3].

According to Report on the results of basic health Research, Health Ministry Republic Indonesia in 2018 [4], the percentage of anemia in females was $23.8 \%$ and males $18.4 \%$. As for age groups, $26.4 \%$ occurred in the age group of 5-14 years and $18.4 \%$ in the age group 15-24, the number of sufferers living in urban $20.6 \%$, rural $22.8 \%$, while the number of anemia sufferers in Indonesia reached $21.7 \%$. The prevalence rate of anemia in Indonesia, which is in adolescent females $26.50 \%$, in women of childbearing age 26.9\%. Anemia in adolescents can reduce work productivity, inhibit growth, easily become infected, reduce physical fitness, and reduce enthusiasm for learning and achievement [5]. The average level of hemoglobin in adult women in 17 provinces in Indonesia is still low, and the lowest position is occupied by North Sumatra with a prevalence of $15.6 \%$ [4].

Teenagers are the psychological and social transition times of children to adulthood that will last until the late teens or early twenties. There are several factors that affect the puberty rates, such as nutrient intake, genetics, health conditions, social, nutritional attitudes, and environmental factors. Nutrition is the strongest and most obvious factor 
affecting puberty. Women are very sensitive to nutrition because malnutrition in women can contribute to the fetus' health that will occur in the future $[6,7]$.

The WHO encouraged that average food energy consumption daily was $10-15 \%$ derived from proteins, $15-30 \%$ from fat, and $55-75 \%$ from carbohydrates [8]. The most important factors are the intake of energy, proteins, and iron. An imbalance in energy intake amount can cause low intake of iron which resulting in iron absorption limitation [9]. Substances that can inhibit iron absorption include caffeine, tannins, oxalate, phytate, which are found in soybean products, teas, and coffee. [10]. Nutrients intake level is divided into five categories, namely weight deficit $(<70 \%$ Recommended Dietary Allowance/RDA), moderate level deficit (70\%-79\% RDA), low-level deficit (80\%-89\% RDA), normal (90\%-119\% RDA), and above the adequacy rate (> $120 \%$ RDA) [11]. Eating habits in adolescence can affect the health after maturity and elderly. Deficiency of nutrients can cause adolescents to experience anemia that causes fatigue, difficult to concentrate, so that the teenagers become less productive at their working age. Teenage women need to consume more iron, because menstruation period in every month might cause the lack of iron in the blood, a factor to trigger anemia [12].

Based on the lifecycle, iron-nutritional anemia at adolescence have a major influence on pregnancy and childbirth. The iron shortage might cause the occurrence of abortion, babies born with low birth weight, negative impact of childbirth because the uterus is unable to contract well, and the risk of post-natal bleeding that causes maternal death [13].

Stick Fish is one type of snack or pastries with the basic ingredients of wheat flour, tapioca flour or sago flour, fats, eggs and water. The product is shaped long flat, has a savory flavor and crunchy texture and cooked by frying method. One type of fishes that can be used as the raw material of fish sticks is lemuru (Sardinella lemuru). Lemuru is usually consumed as fresh and processed fish and has a high protein content at an economical price [14].

In current situation, supplement containing iron/ $\mathrm{Fe}$ is expected to overcome anemia in adolescents. It is expected that the intake of lemuru stick as a food snacks can be used as an alternative to increase hemoglobin levels in young women suffering from anemia. The aim of this community service was to increase the knowledge of young women, especially those suffering from anemia, about the management of blood hemoglobin levels. 


\section{Methods}

The community service activities were held at SMA Nusantara Lubuk Pakam in August 2019. The activities were carried out by doing counseling on anemia and the benefit of the stick of lemuru fish (Lemuru sardinella), the measurement of hemoglobin level of young women students, and demonstration of how to produce lemuru fish stick.

The target of this community service were all students of year X, XI, XII in the SMA Nusantara Lubuk Pakan. The selection of respondents were done by firstly screening by using the following criteria: level of $\mathrm{Hb}<12 \mathrm{~g} / \mathrm{dl}$, not in menstruation period condition, not being consumed supplements that increase the level of $\mathrm{Hb}$, physically healthy and not in illness state. Based on the screening results, 32 young women respondents were met the criteria, whom they were considered having anemia.

Evaluation of the activity was done by providing pre-tests and post-test of students' knowledge about anemia. The assessment was done before and after the community services activities completed. The indicators used in the evaluation of the implementation of activities can be seen in Table 1 .

Table 1. The successful indicators of community services program

\begin{tabular}{|c|c|c|}
\hline No & Activities & Successful indicators \\
\hline 1 & $\begin{array}{l}\text { Counseling on the benefits of a } \\
\text { lemuru stick to increase blood } \\
\text { hemoglobin levels in young women }\end{array}$ & $\begin{array}{l}\text { - Participants followed the } \\
\text { counseling from beginning } \\
\text { until the end of activities } \\
\text { - Participants were able to } \\
\text { answer questions orally at the } \\
\text { end of the activity }\end{array}$ \\
\hline 2 & $\begin{array}{l}\text { Demonstration of lemuru fish stick } \\
\text { making }\end{array}$ & $\begin{array}{l}\text { - Participants can makeg lemuru } \\
\text { fish sticks according to } \\
\text { prescribed procedures }\end{array}$ \\
\hline
\end{tabular}

Pre-tests activities were done by giving the questioner to participants, containing questions about anemia. Then the activity was continued by providing the counseling about anemia and demonstrating the fish stick making, as well as introducing lemuru fish and their benefits. The fresh lemuru fish and lemuru fish stick obtained from the results of the demonstration activities are shown in Figures 1(A) and 1(B), respectively. After counselling and demonstration activities to make a lemuru fish stick, then post-test was undertaken to know the participants' ability on the topics in the given material. 

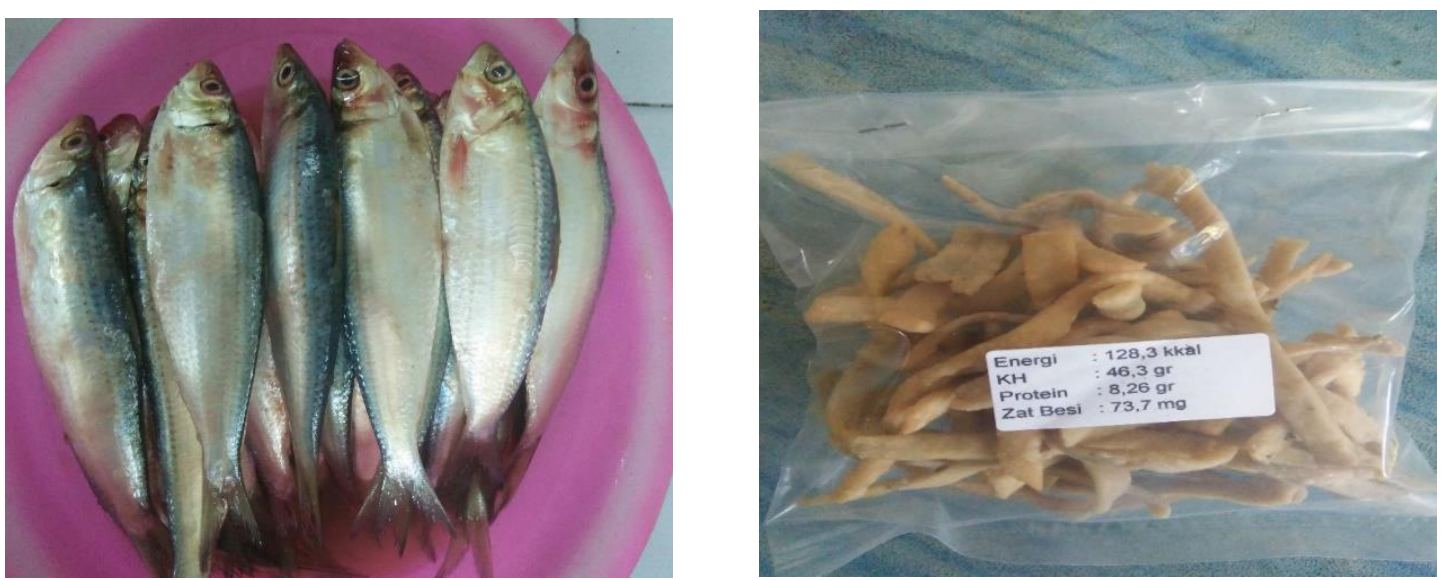

Figure 1. The fresh lemuru fish (A) and the lemuru fish snack (B)

\section{Results and Discussion}

The community service activities were carried out by counseling methods and demonstration of lemuru fish stick making as a snack. The snacks were expected to help in overcoming if anemia problem and increase the haemoglobin level in young women. Activities conducted consist of several stages, namely: 1) Pre-test, 2) Examination of blood hemoglobin level, 3) provide counseling about anemia, 4) demonstration the manufacture of the stick making fish Lemuru, 5) post-test, and 6) assessment of activities.

The pre-test was aimed to determine the previous knowledge young women at SMA Nusantara on anemia before the activities were done. The pre-test results showed thant only $60 \%$ of the participants can answer 15 questions correctly.

The results of the participants' hemoglobin test showed that the average rate $\mathrm{Hb}$ of 32 young women was $11.35 \mathrm{~g} / \mathrm{dl}$, and the remaining 2 students had a hemoglobin level of 9.8 and $10.1 \mathrm{gr} / \mathrm{dl}$. These results suggest that the blood $\mathrm{Hb}$ level of the young women's was low. In addition, there were found some clinical signs such as weakness, fatigue, lethargic, weakness in students who have low Hb levels. Based on the interviews to the young women, it is known that the they are often sleepy during school tuition hours.

The nutrition composition of lemuru fish snack obtained from the demonstration activities of the Lemuru stick is shown in Table 2. A lemuru stick has an energy of $128.3 \mathrm{kcal}$, in which the energy is the main nutritional needs of human beings. When the requirement of energy is not fulfilled in human body, then the needs of other nutrients (proteins and minerals) will not be met. For example, the limitation of mineral iron, which is required in forming of red blood cells, can eventually lead to the decrease of blood haemoglobin levels. Energy is important to maintain a basic function of the body, 
in which the basal metabolism needs $60-70 \%$ from total energy requirement. The energy is necessary for carrying out body functions such as digestion, processing and absorbing food in the digestive tract, as well as for moving, walking, working and other activities. Sources of energy can be on the rice, bread, potatoes, tubers, fruit of granulated sugar, pumpkin, macaroni, dried noodles, corn [15].

Table 2. Nutrition composition of lemuru fish stick per $100 \mathrm{~g}$

\begin{tabular}{lcc}
\hline Composition & Amount & Analysis Methods \\
\hline Protein $(\mathrm{g})$ & 8.26 & SNI 01-2891-1992 \\
Carbohydrate $(\mathrm{g})$ & 46.3 & SNI 01-2891-1992 \\
Energy (kcal) & 128.3 & SNI 01-2891-1992 \\
Fe $(\mathrm{mg})$ & 73.7 & Atomic Absorption Spectrophotometry \\
\hline
\end{tabular}

Energy deficiency can cause anemia, because protein will be used as source of energy, so the protein needed for the formation of red blood cells will be reduced. If the body is deficient in protein, the transportation of iron into the blood plasma will be interrupted, affecting the Hemoglobin level. Lemuru fish stick has a protein content of $8.26 \mathrm{~g}$ in 100 g.

The content of iron in a lemuru fish stick is $73.3 \mathrm{mg}$, so that Lemuru stick intake might be able to overcome the problem of low levels of $\mathrm{Hb}$ in patients with anemia. Iron is the micro element most contained in the human and animal body. Iron plays a role in oxygen transport, electron transport in the cell and part of the enzyme reaction in the body tissues. Iron in the form of iron compounds functions as a forming of haemoglobin (Hb) [16].

The body requires $26 \mathrm{mg}$ of iron per day. Supplementation of iron tablets in young women for 3-4 months may increase hemoglobin levels. This is due to the life of red blood cells only about 3 months, while erythrocyte only lasts for 120 days. Therefore, $1 / 20$ cells of erythrocytes should be replaced daily [16]. If the body cannot absorb iron (Fe) from the food as much as it is every day, then iron supplementation of added blood tablets is crucial. Supplementation is expected to provide nutrients that can help to correct the state of nutritional anemia. Based on the results of the research, anemia in Indonesia is largely caused by iron deficiency [17]. Therefore, the provision of lemuru fish stick might be able to overcome the problem of anemia without consuming blood supplement tablets.

At the end of community service activities, post-test was undertaken. The results showed that $80 \%$ of the participants can answer the questions correctly (Table 3). In 
other words, participants' understanding increased by $20 \%$ after the extension and demonstration activities.

Table 3. Knowledge score during pre and post-test of young women respondents at SMA Nusantara Lubuk Pakam

\begin{tabular}{cccccc}
\hline \multirow{2}{*}{ Variable } & \multirow{2}{*}{$\begin{array}{c}\text { Average } \\
(\%)\end{array}$} & \multicolumn{2}{c}{ Number of Answer Correct } \\
\cline { 5 - 6 } Knowledge & Pre test & 32 & 60 & Minimum & Maximum \\
& Post test & 32 & 80 & 8 & 12 \\
\hline
\end{tabular}

This result is in line with previous studies stating that there was an increase in knowledge scores after being given training on nutritional knowledge [18]. Another study also conveyed a similar result that there were $15 \%$ increased scores of cadre knowledge after being given the counseling of obesity and hypertension for posyandu cadres. The increase in knowledge is statistically significant, that might be caused by the method used, namely the combination of conventional lecture methods with demonstrations. In addition, the young women are very passionate to listen to counselling and see the demonstrations, that might enhance their understanding on the topics given to them.

\section{Conclusions}

The level of knowledge of young women in SMA Nusantara Lubuk Pakam has increased, after the community service activities on the haemoglobin level management by the intake of lemuru stick fish. The combined extension activities increase public knowledge from $60 \%$ to $80 \%$ after counseling. Feeding lemuru fish stick might be able to overcome anemia problem without consuming blood supplement tablets.

\section{References}

[1] Arisman, M.B. 2010. Buku Ajar Ilmu Gizi Dalam Daur Kehidupan. [Teaching Book: Nutrition in Life Cycle] $2^{\text {nd }}$ Ed. EGC - Jakarta.

[2] Labenjang, E.R., Mulyadi, Ns, Lolong, J. 2014. Hubungan antara anemia dengan hasil belajar siswi SM Negeri 3 Sapa Kecamatan Tenga Kabupaten Minahasa Selatan [The relationsjip between anemia and learning outcome of students in SMP Negeri 3 Sapa Tenga District South Minahasa Regency]. J. Keperawatan 2(2).

[3] Indratanti, D., Kartini, A. 2014. Hubungan Status Gizi Dengan Kejadian Anemia Pada Remaja Putri [Relationship of nutritional Status with incidence of Anemia in young women]. Journal of Nutrition College 3(2) : 310-316.

[4] Health Ministry Republic Indonesia. 2018. Laporan Hasil Riset Kesehatan Dasar (Riskesdas) Indonesia tahun 2017. [Report on the results of basic health Research (RISKESDAS) Indonesia in 2013]. Health Research dan Development Agency, Health Ministry Republic Indonesia, Jakarta. 
[5] Thomas, D., Chandra, J., Sharma, S., Jain, A., Pemde, H.K. 2015. Determination of nutritional anemia in adlescents. Indian Pediatrics, 52: 867 - 869.

[6] Cetin, I., Berti, C., Calabrese, S. 2009. Role of micronutrients in the pereinceptional period. Human Reproduction Update, 16(1): 80 - 95.

[7] Wolde, T., Amanu, W., Mekonnin, D., Yitayin, F., Abu, F., Dufera, F., Birhan, T., Ejeta, E. 2014. Ntritional status of adolescent girls living in Southeast $\mathrm{f}$ Ethiopia. Food Science and Quality, 34: 58 - 64.

[8] WHO (World Health Organization). 1985. Energy and Protein Requirements. Report of a Joint FAO/WHO/UNU Expert Consultation. Technical Report Series 724. World Health Organization, Geneva. 206 pp.

[9] Zhang, Q., Qin, G., Liu, Z., Li, Z., Li, J., Varma, D.S., Wan, Q., Zhao, J., Min, X., Han, X., Liu, M. 2018. Dietary balance index-07 and the risk of anemia in middle age and eldery people in Southwest China: A cross sectional study. Nutrients, 10(2): 162.

[10] Masthalina, H., Laraeni, Y., Dahlia, Y.P. 2015. Consumption patterns (Factor inhibitors and Enhancer $\mathrm{Fe}$ ) to status of anemia adolescent. Jurnal Kesehatam masyarakat, 11(1): 80-86.

[11] Sudrajat, A.S. Sinaga, T. 2016. Cost Analysis towards the Availability of Food as well as the Nutritional Adequacy Level of Santri in Darul Arqam Boarding School Garut. Gizi Indonesia, 39(2): 115-124.

[12] World Health Organization, Global Nutrition Targets 2025: Anemia Policy Brief, 2014, https://www.who.int/nutrition/publication/globaltargets2025policybrief anemia/en/.

[13]Listiana, A. 2016. Analisis Faktor-Faktor yang Berhubungan dengan Kejadian Anemia Gizi Besi pada Remaja Putri di SMK Negeri 1 Terbanggi Besar Lampung Tengah [Analysis of factors related to the incidence of iron nutrient Anemia in young women in SMK Negeri 1 Terbanggi Besar Central Lampung] Jurnal Kesehatan, VII(3): 455-469. https://doi.org/10.26630/jk.v7i3.230

[14] Irfan, M. 2015. Manajemen Proses Produksi Stick Ikan Lemuru (Sardinella Lemuru) Di Balai Hasil Pengolahan Perikanan dan Kelautan (BHPPK) Pelabuhan Perikanan Nusantara Prigi, Kabupaten Trenggalek, Jawa Timur [Management of the lemuru fish stick production process (Sardinella Lemuru) at the Fisheries and Marine Processing Agencies (BHPPK) Pelabuhan Perikanan Nusantara Prigi, Kabupaten Trenggalek, Jawa Timur]

[15]Afandi, F.A., Wijaya, C.H., Faridah, D.N., Suyatma, N.E. 2019. Relationchip between carbohydrate content and the glycemic index in high-carbohydrate foods.

[16] Abbaspour, N., Hurrel, R., Kelishadi, R. 2014. Review on iron and its importance for human health. J. Res. Med.Sci., 19(2): $164-174$.

[17] Priyanto, L.D. 2018. The relationship of age, educational background, and physical activity on female students with anemia. Jurnal Berkala Epidemiologi, 6(2): 139 146.

[18]Lubis, Z. Syahri, I.M. 2015. Knowledge and action cadres on growth monitoring of children under five years. Jurnal Kesehatan Masyarakat, 11(1): 65 - 73. 